\title{
IMPACT RESISTANCE OF GYPSUM BOARD SUBJECTED TO LOW VELOCITY IMPACT
}

\author{
Memduh Kara, Müfit Metinöz, Mesut Uyaner
}

Original scientific paper

The aim of this study was to investigate the impact resistance and damage behaviour of gypsum and composite gypsum boards subjected to low velocity impact. Low velocity impact tests were performed on four different board materials which can be listed as gypsum boards, gypsum $+75 \mathrm{gr} / \mathrm{m}^{2} \mathrm{mesh}$ boards, gypsum+wallpaper boards and gypsum $+75 \mathrm{gr} / \mathrm{m}^{2} \mathrm{mesh}+$ wallpaper boards. Indenter used in the impact tests was $24 \mathrm{~mm}$ in diameter and has semi spherical tip geometry. Gypsum and composite gypsum boards were bonded in $500 \times 400 \mathrm{~mm}$ sizes and simply supported at four sides. Various energy levels, i.e. 2, 4, 6, 8, 10 and $12 \mathrm{~J}$ were applied to the centre of each board. As a result of low speed impact tests, impact force-time and force-displacement variations were obtained and the damaged regions of the samples were examined. Penetration thresholds and perforation thresholds of gypsum and composite gypsum board samples were determined by using Energy Profile Method (EPM). The effect of adding mesh and wallpaper into the gypsum board on stab and puncture limits was evaluated. Around $62.40 \%$ increase occurred on gypsum+mesh+wallpaper board comparing to gypsum board in perforation thresholds.

Keywords: EPM method; impact resistance; gypsum board; low velocity impact

Otpornost na udar gipsane ploče izložene udaru male brzine

Izvorni znanstveni članka

Cilj ovoga rada je istražiti otpornost na udar i ponašanje kod oštećenja gipsanih i složenih gipsanih ploča izloženih udaru male brzine. Ispitivanja udara male brzine provedenu su na četiri različita materijala ploča, i to gipsane ploče, gips $+75 \mathrm{gr} / \mathrm{m}^{2} \mathrm{mrežaste} \mathrm{ploče,} \mathrm{ploče} \mathrm{od} \mathrm{gipsa+zidna} \mathrm{tapeta} \mathrm{i} \mathrm{ploče} \mathrm{od}$ gipsa+75 gr/m² mreže+tapeta. Udubljenje korišteno u udarnim ispitivanjima bilo je $24 \mathrm{~mm}$ u promjeru i geometrije polu kuglastog tipa. Gipsane i složene gipsane ploče bile su spojene u veličinama od $500 \times 400 \mathrm{~mm}$ i jednostavno pridržavane na četiri strane. Na sredinu svake ploče djelovalo se energijom različitih razina: $2,4,6,8,10$ i $12 \mathrm{~J}$. Kao rezultat ispitivanja udara male brzine, dobivene su varijacije udarna sila-vrijeme i sila-pomak te su ispitivana oštećena područja uzoraka. Granice penetracije i granice perforacije uzoraka gipsanih i složenih gipsanih ploča određene su EPM metodom (Energy Profile Method). Procijenio se učinak dodavanja mreže i tapete u gipsanu ploču na granice izdržljivosti kod udaranja i probijanja. Na ploči od gipsa+mreža+tapeta došlo je do porasta granice perforacije od oko $62.40 \%$ u usporedbi s gipsanom pločom.

Ključne riječi: EPM metoda; gipsana ploča; otpornost na udar; udar male brzine

\section{Introduction}

Gypsum board which is a lightweight, fire resistant, and a good sound isolating material, is widely used in construction and decoration works because of having any desired shape, easy and fast applications. Gypsum board may be subject to an impact during production, maintenance, and usage. Subjecting to impacts in various ways such as hitting gypsum plate during moving the stuff, punching, elbow throwing, kicking can be shown as examples for impacts during the usage. In this case, their speeds are low but the effects are high. Gypsum boards are more susceptible to impact damage comparing to the other building components. Damages of gypsum boards caused by the impacts affect the heat transfer as well as the strength of the material. This is a limiting factor in the use of gypsum boards. For these reasons, low velocity impact problem of gypsum plates represents significant theoretical and practical applications.

Many studies have been carried out regarding the evaluation of physical and mechanical behaviours of ceramic matrix composite materials especially cementbased ones (Chandrasekaran et al. [1]; Sageresan et al. [2]; Kumar and Barai [3]; Voyiadjis et al. [4]). However, research related with the other building materials remained inadequate. There are some studies performed to develop physical and mechanical properties of gypsum material. Wu and Dare [5] investigated the axial and shear behaviour of glass fibre reinforced gypsum (GFRG) wall plate. Cyclic shift tests were performed by $\mathrm{Wu}$ [6] in order to investigate the effect of reinforcement continuity on GFRG wall shifts behaviours. Mechanical properties, acoustic absorption properties and thermal conductivity of cork-gypsum composites are investigated by HernandezOliveras et al. [7] experimentally. Eve et al. [8] examined the mechanical behaviour and microstructure of plaster composites containing polyamide fibre. Jamshid et al. [9] carried out a research about improving bond strength between fibre and matrix in aluminium fibre reinforced plaster composites. Some studies have been conducted related with the investigating thermal and thermo-physical properties of gypsum materials (Mehaffey et al. [10]; Sultan [11]; Thomas [12]; Ghazi and Hugi [13]). Even though many studies are carried out about low velocity impact tests of fibre reinforced concrete materials (Buzzini et al. [14]; Chen and May [15]; Hummeltenberg et al. [16]; Kishi et al. [17]; Mougin et al. [18]; Schellenberg [19]; Zineddin and Krauthammer [20]), any study related to impact behaviours of plaster composite materials has not been found.

In this study, in order to determine low velocity impact behaviours of gypsum and composite gypsum boards, low velocity impact tests were performed in different energy levels on test samples. Accordingly, impact tests are conducted in $2 \mathrm{~J}, 4 \mathrm{~J}, 6 \mathrm{~J}, 8 \mathrm{~J}, 10 \mathrm{~J}$ and $12 \mathrm{~J}$ impact energies. Impacts are made by using semi spherical tip striker on midpoint of the samples placed on sample table. Damaged area of each samples damaged as a result of low velocity impact in various energy levels is examined and discussed. In addition, by determining stabbing and puncture limits of the samples with EPM, the effect of reinforcement materials added into the gypsum plate is evaluated. 


\section{Experimental works}

This study focused on the impact resistance of composite gypsum boards therefore it is important to choose proper reinforcement material. Three different reinforcement materials were chosen for composite gypsum boards.

\subsection{Preparation of the test sample}

Test samples used in this study are selected as gypsum plate, gypsum plate+mesh, gypsum plate+wallpaper, gypsum plate+mesh+wallpaper, respectively. The thickness of gypsum board was $15 \mathrm{~mm}$. Test samples are manufactured and prepared by cutting in the desired sizes.

\subsection{Drop weight test device}

In this study, a special drop weight test device developed in Engineering and Architecture Faculty in Selcuk University is used (Fig. 1). The device is $1.4 \mathrm{~m}$ high. Striker which has semi spherical tip geometry has $6.350 \mathrm{~kg}$ mass and is able to fall freely from $1.0 \mathrm{~m}$. There is a locking mechanism in order to release the mass from a desired distance. Thus, tests in various impacts energies and velocities can be performed.

Force variation data are recorded by force sensors from the beginning of the impact to the end and shown in force versus time graph via recorded computer software. Contact force-displacement changes are obtained as a result of kinetic analysis of low velocity impact (Uyaner and Kara [21]).

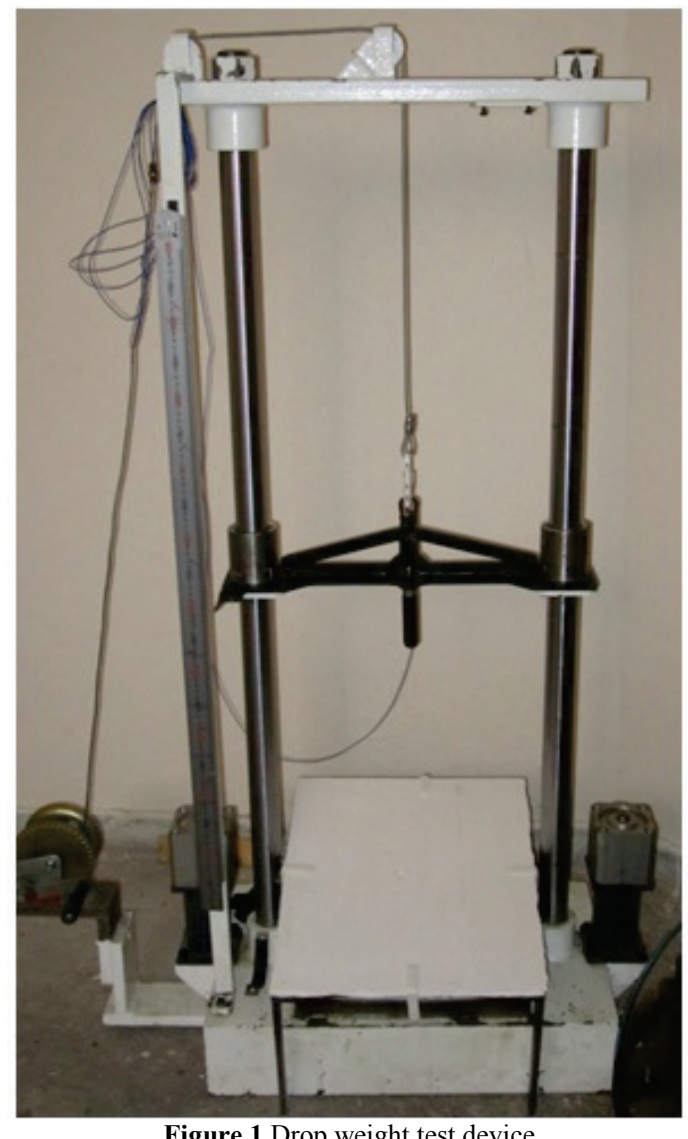

Figure 1 Drop weight test device

\section{Results and discussion}

In this work, the impact resistance and damage behaviour of gypsum and composite gypsum boards subjected to low velocity impact were investigated experimentally. For better understanding of impact response, penetration thresholds and perforation thresholds of gypsum and composite gypsum board samples were determined.

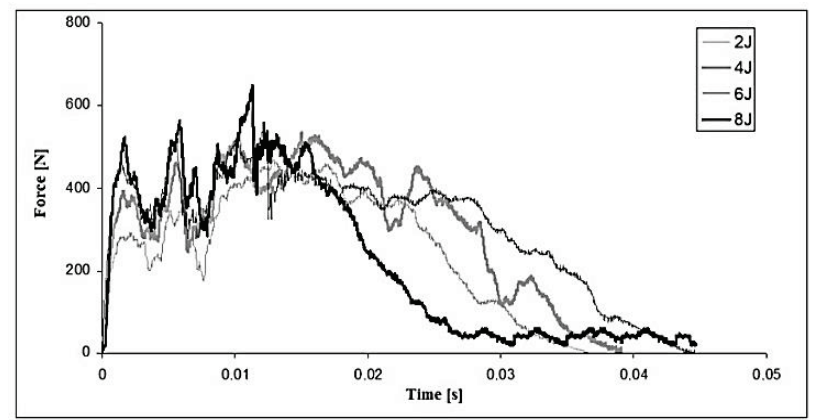

(a)

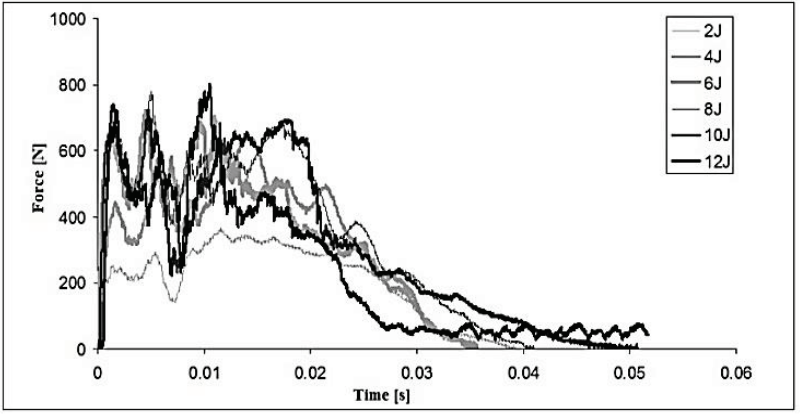

(b)

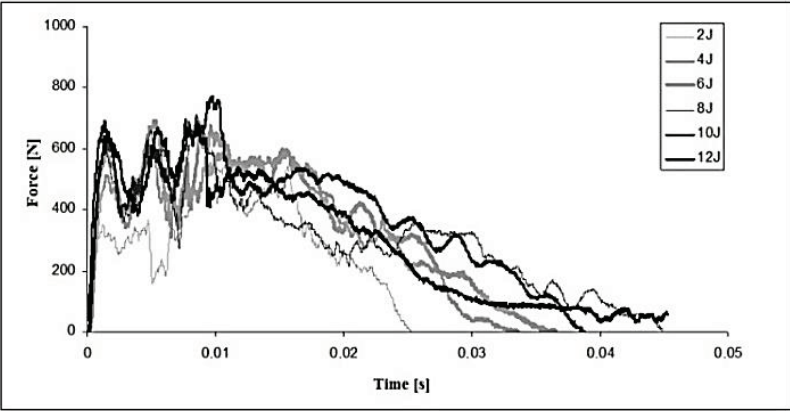

(c)

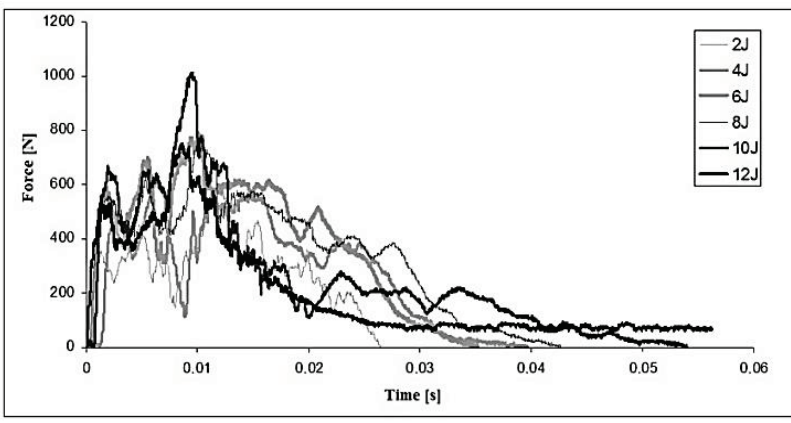

(d)

Figure 2 Contact force and time histories for a) gypsum board, b) gypsum+mesh, c) gypsum+wallpaper and d) gypsum+mesh+wallpaper samples for various impact velocities

\subsection{Contact forces}

Contact force-time variations can be seen in Fig. 2 for a) gypsum b) gypsum+mesh c) gypsum+wallpaper d) 
gypsum+mesh+wallpaper test samples. In all figures, the force reaches a maximum value by rapidly increasing and then it goes to zero for the impact occurred with rebound and stuck. In the samples where the puncture occurred, the force does not go to zero, force-time curve moved parallel to the horizontal axis with the effect of friction. A lot of oscillations are observed in the increasing part of force-time curves in all graphs. These oscillations indicate the damages occurred in the sample.

In plain gypsum board samples, rebound occurred for 2 and $4 \mathrm{~J}$ impact energy levels, stuck occurred for $6 \mathrm{~J}$ and puncture occurred for $8 \mathrm{~J}$ impact energy levels so the tests for 10 and $12 \mathrm{~J}$ were not carried out for them. When the impact energy is increased in these samples, the biggest contact force also increased. In gypsum+mesh samples, rebound occurred for 2, 4 and $6 \mathrm{~J}$ impact energy levels, stuck occurred for 8 and $10 \mathrm{~J}$ and puncture occurred for $12 \mathrm{~J}$ impact energy levels. The highest contact force shows increment until $8 \mathrm{~J}$ impact energy where the stuck occurred and decrement is observed in 10 and $12 \mathrm{~J}$ impact energy levels. In gypsum+wallpaper samples, rebound occurred for 2, 4 and $6 \mathrm{~J}$ impact energy levels, stuck occurred for 8 and $10 \mathrm{~J}$ and puncture occurred for $12 \mathrm{~J}$ impact energy levels. The highest stuck force showed increment until $10 \mathrm{~J}$ impact energy level where the stuck occurred from gypsum+mesh samples and fell down again at $12 \mathrm{~J}$ impact energy level. In gypsum+mesh+wallpaper samples, rebound occurred for 2, 4, 6 and $8 \mathrm{~J}$ impact energy levels, stuck occurred for 10 $\mathrm{J}$ and puncture occurred for $12 \mathrm{~J}$ impact energy levels. The highest stuck force showed increment until $10 \mathrm{~J}$ impact energy level where the stuck occurred and fell down at $12 \mathrm{~J}$ impact energy level.

\subsection{Contact force-displacement}

Force-displacement changes in gypsum plate, gypsum + mesh, gypsum+wallpaper and gypsum+mesh+wallpaper samples can be seen in Fig. 3 .

Force-displacement graphs obtained from various impact energy levels from gypsum plate samples are seen in Figure 3a. The curves obtained for 2 and $4 \mathrm{~J}$ impact energies are a closed type curve because the rebound occurs in those energy levels. While the curve obtained in $6 \mathrm{~J}$ impact energy level, it is in the transition region to the open type curve. This energy level is the one where the striker tip stuck to the sample. Since $8 \mathrm{~J}$ impact energy is the energy level where the perforation occurs, the obtained curve is open type.

A lot of oscillation is observed in force-displacement changes obtained for all samples in this study. The oscillation amount is lower in force-displacement graphs obtained from the studies where impact behaviors of layered composite materials are investigated. High amount of oscillation in the graphs obtained from gypsum board and doped gypsum board samples is related with impact damage mechanism occurring in the samples. Collapse and crush amount in the region where the striker contacts with the samples during impact are a lot more comparing to the layered composite materials. Since the resistance shown by gypsum material against crushing and compaction is weak, too much oscillation occurs in force-displacement curves.

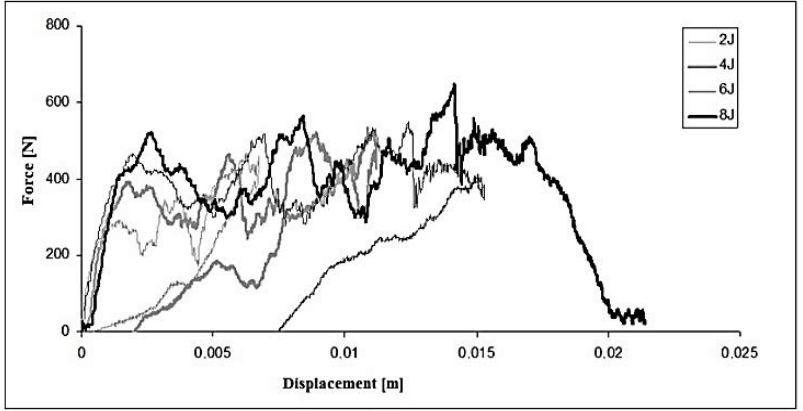

(a)

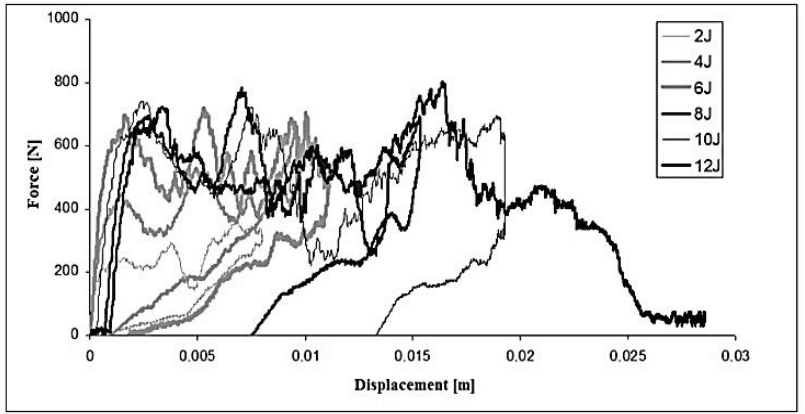

(b)

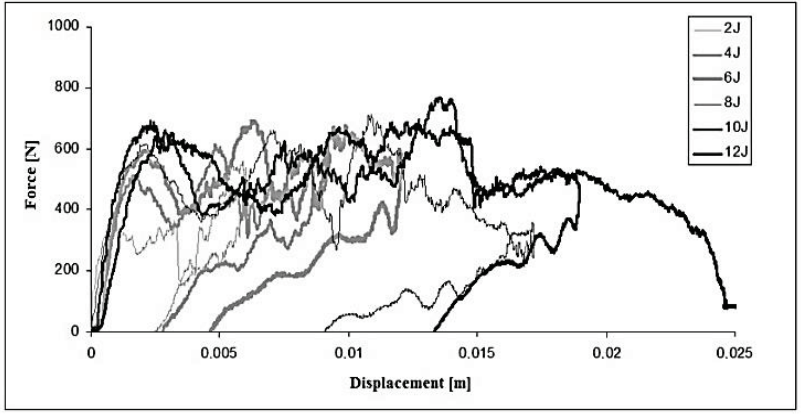

(c)

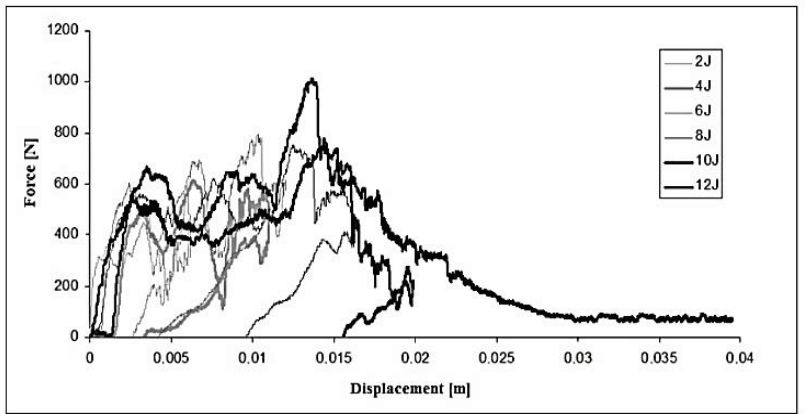

(d)

Figure 3 Contact force and displacement histories for a) gypsum board, b) gypsum + mesh, c) gypsum+wallpaper and d)

gypsum+mesh+wallpaper samples for various impact velocities

\subsection{Energy profile method}

The correlation between impact energy and absorbed energy can be found using Energy profile method (EPM) (Liua et al. [22]). Energy profile variations are seen in Fig. 4 for gypsum board, gypsum + mesh, gypsum+wallpaper and gypsum+mesh+wallpaper samples for various impact velocities.

Energy profile diagram belonging to gypsum board is given in Fig. 4a. High amount of energy and rebound were seen to have occurred in $2 \mathrm{~J}$ and $4 \mathrm{~J}$ impact energy levels. This excessive energy is used in rebound at striker tip. While the impact energy and absorbed energy is almost equal in $6 \mathrm{~J}$ impact level, stuck occurred in the 
sample. A puncture occurred in the samples in $8 \mathrm{~J}$ impact energy. The energy absorbed by the sample remains constant after the puncturing limit. No matter how much the impact energy in striker tip increases, damages will not occur in the samples.

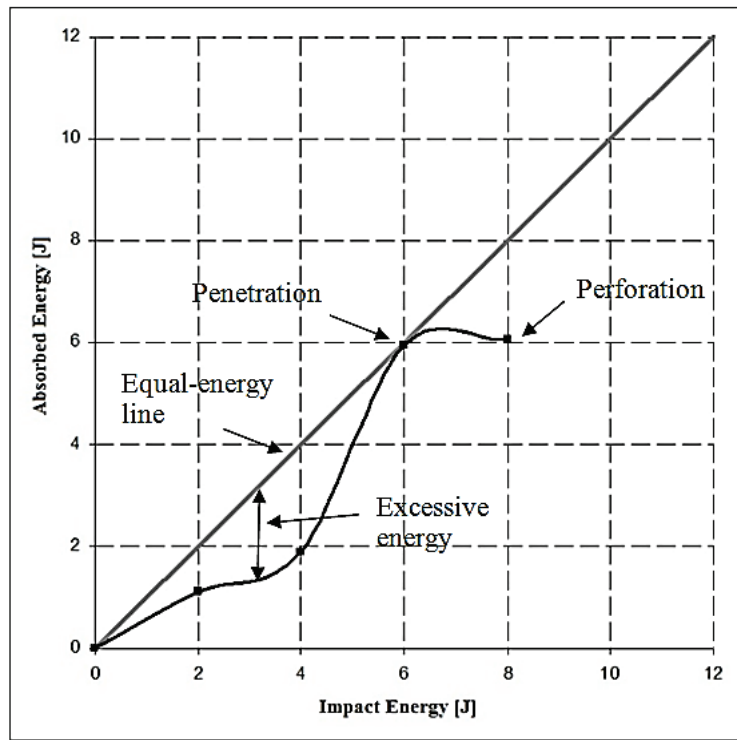

(a)

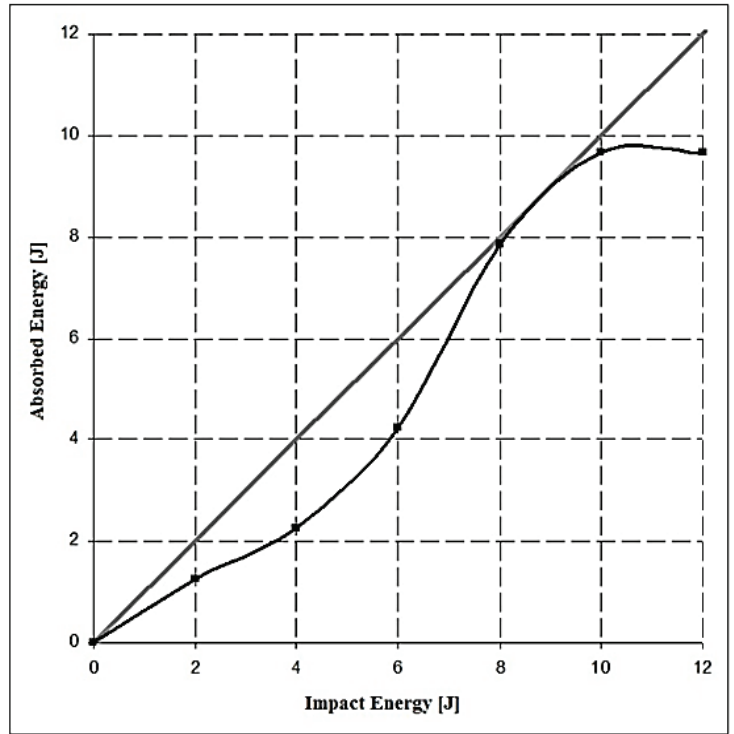

(c)
From the test, it is observed that the highest puncture limit is in gypsum+mesh+wallpaper sample and the perforation thresholds are increased by $62.4 \%$ comparing to gypsum board.

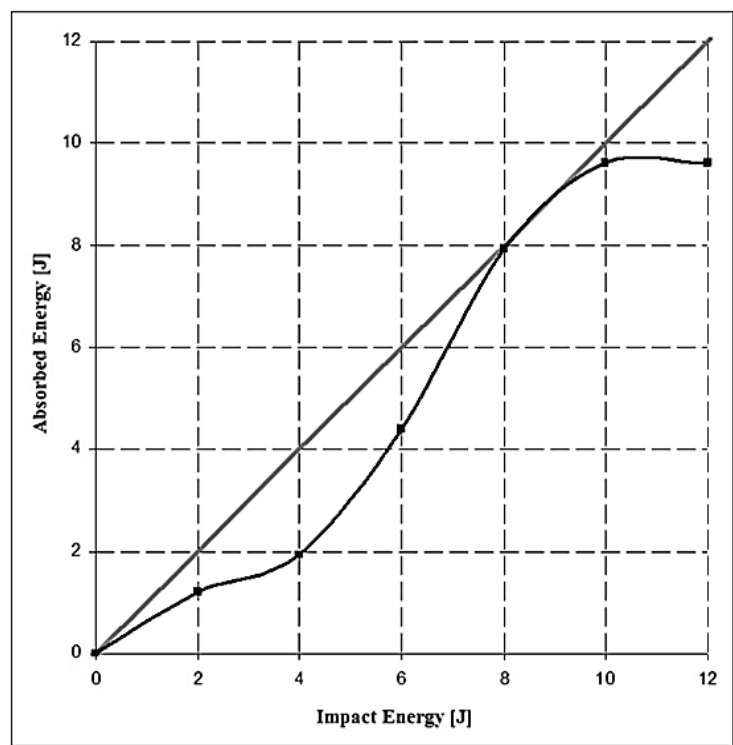

(b)

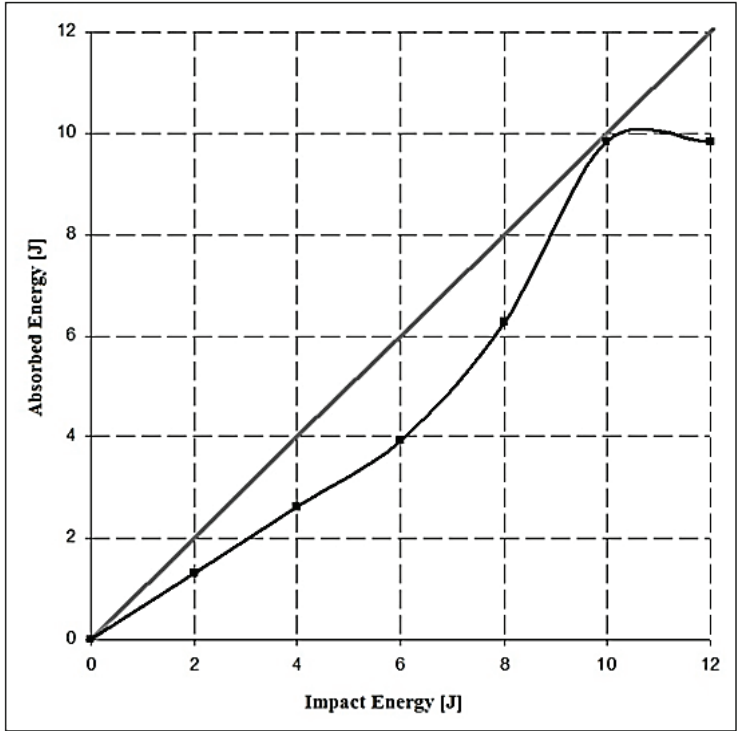

(d)

Figure 4 Energy profile variations for a) gypsum board, b) gypsum+mesh, c) gypsum+wallpaper and d) gypsum+mesh+wallpaper samples for various impact velocities

\subsection{Damage analysis}

Macro scale impact damages occurred in composite gypsum boards. After the impact made in test samples, high resolution pictures of the front and back side of the damaged regions were taken. Front and back damaged regions for gypsum board, gypsum board + mesh, gypsum+wallpaper and gypsum+mesh+wallpaper samples subjected to low velocity impact, are seen in Figs. 5, 6, 7, 8, respectively.

In all low velocity impact test samples, the damage occurred in the front side subjected to the impact is observed to be lower than the back side. While damages caused by compression as a result of impact occur, damages caused by tension occur at the back surfaces.
Damages caused by the tension are more than those caused by compression.

In the tests performed for $2 \mathrm{~J}, 4 \mathrm{~J}$ impact energies on gypsum plate samples, bouncing occurred on gypsum plate. Stabbing occurred on gypsum plates in the test performed at $6 \mathrm{~J}$ impact energy. Puncture occurred on the gypsum plate in the test made at $8 \mathrm{~J}$ impact energy. While penetration region of the striker is seen on the front side of the sample in Fig. 5a, no damage is observed at the back side. Penetration zone formed in front side of the sample is seen in Fig. 5b. It is seen that swelling type damage occurred at the back surface of the sample and it is almost 8 times bigger than the one in front of the area. In $6 \mathrm{~J}$ impact energy, stuck is observed in the front side of the sample in Fig. $5 \mathrm{c}$, but at the back side, impact trace 
area occurred in the front side by striker impact tip causes again 8 times more damages. This damage is in the shape of splitting. Stuck is observed in the front side of the sample in Fig. 5d. Gypsum plate is punctured in $8 \mathrm{~J}$ impact energy and opening occurred at the back side as well as a cracking.

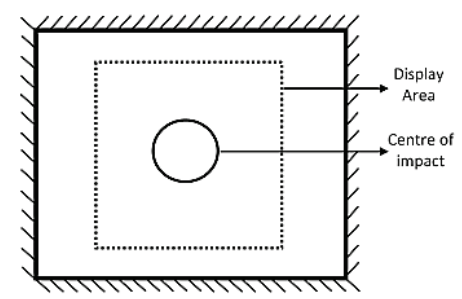

\section{Front view}
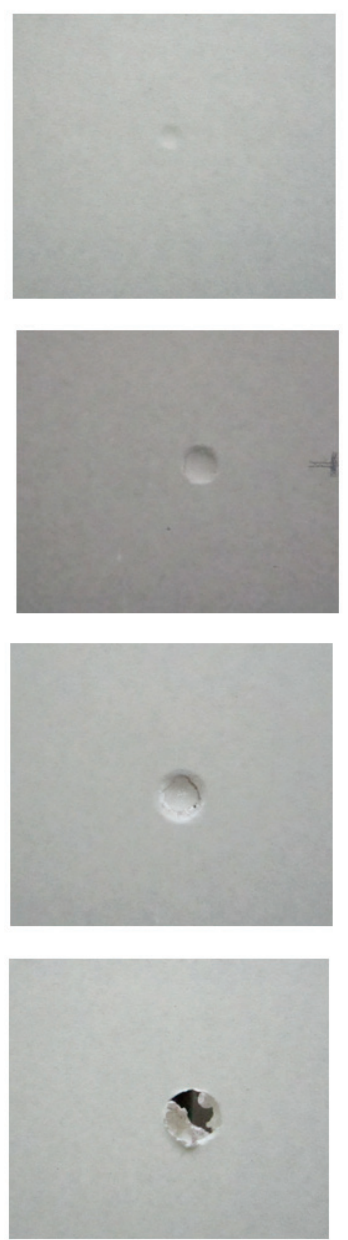

(d)

(b)

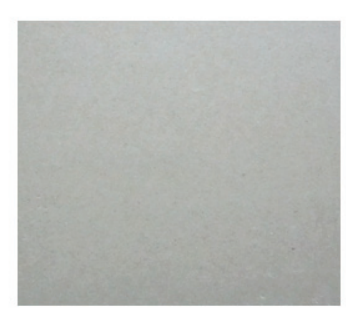

(a)

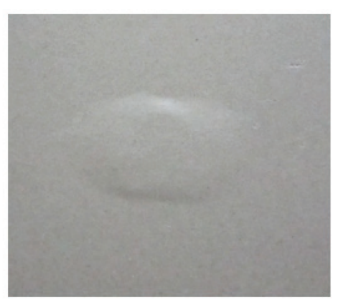

(c)
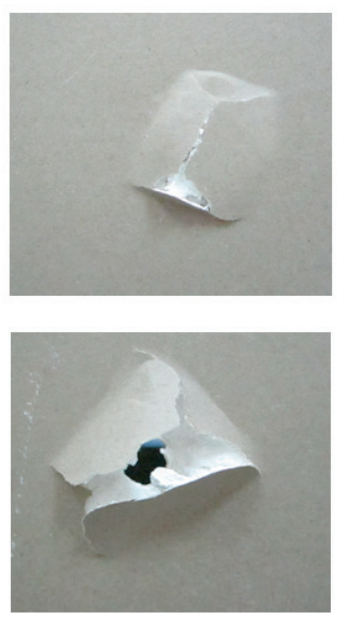

Figure 5 Front and back damaged zones of Gypsum board for (a) $2 \mathrm{~J}$, (b) $4 \mathrm{~J}$, (c) $6 \mathrm{~J}$, (d) $8 \mathrm{~J}$ impact energy levels

Rebound occurred on gypsum plates in the test performed at $2 \mathrm{~J}, 4 \mathrm{~J}, 6 \mathrm{~J}$ impact energies in gypsum + mesh samples. Stabbing is observed on gypsum plate in the test performed at 8 and $10 \mathrm{~J}$ impact energies. Puncture occurred on gypsum plate in the test made at 12 $\mathrm{J}$ impact energy. While penetration area of striker can be seen in Figure 6.a. in the front surface of the sample, no damage is observed at the back side. While striker penetration damage is observed in the front face of the samples in Fig. $6 b \div 6 c$, approximately 8 times bigger damage that the impact trace created by the impact tip on the front side is observed at the back side. While stuck on the front side of the sample is observed in Fig. $6 \mathrm{~d} \div 6 \mathrm{e}$,

explosion is seen at the back side of the samples. An opening is formed together with the explosion at the back side of the gypsum plate in $10 \mathrm{~J}$ impact energy. In $12 \mathrm{~J}$ impact energy, it is seen in Fig. 6f that the sample is punctured and opened by exploding.

\section{Front view}
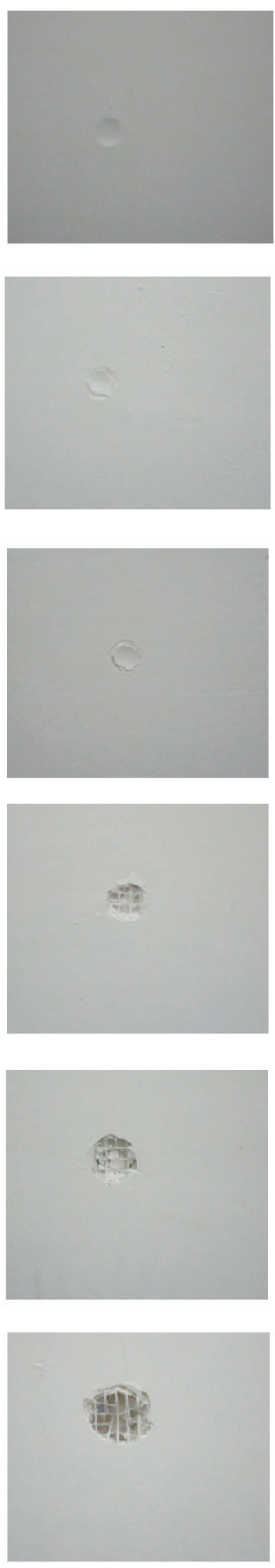

(f)

(c)

(d)

(e)
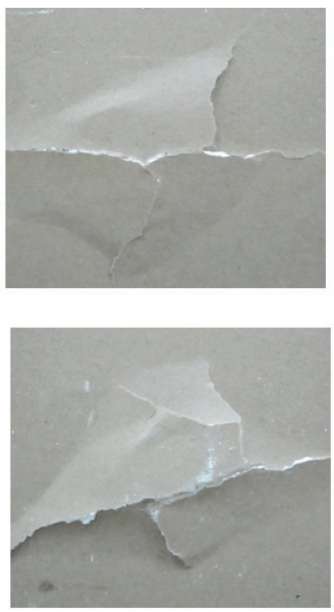

Figure 6 Front and back damaged zones of Gypsum board+mesh for (a) $2 \mathrm{~J}$, (b) $4 \mathrm{~J}$, (c) $6 \mathrm{~J}$, (d) $8 \mathrm{~J}$ (e) $10 \mathrm{~J}$, (f) $12 \mathrm{~J}$ impact energy levels

Front and back side pictures belonging to the impact damages occurring in gypsum+wallpaper samples are given in Fig. 7 and gypsum+mesh+wallpaper samples are given in Fig. 8. 


\section{Front view}

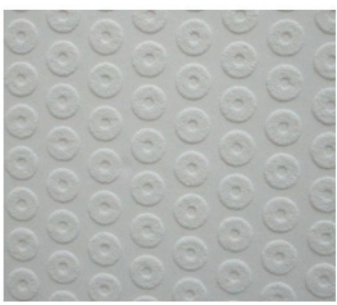

(a)
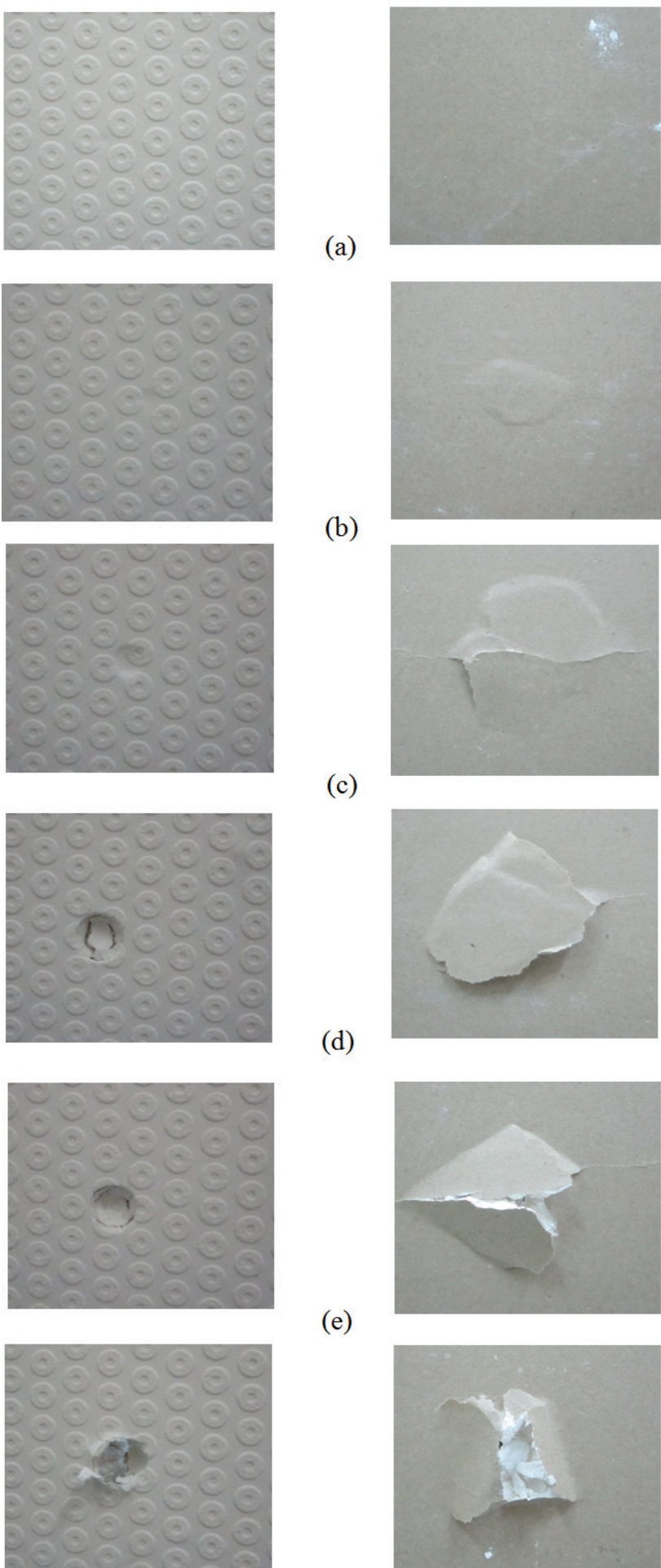

(e)

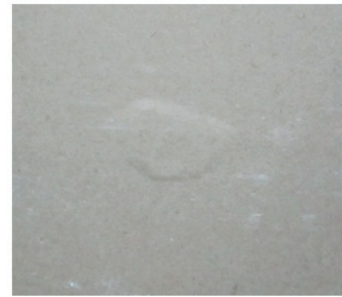

(b)

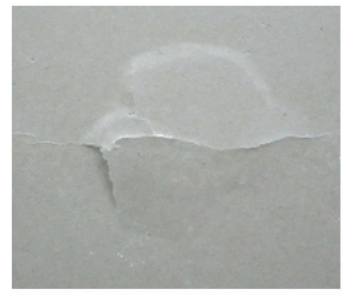

(c)

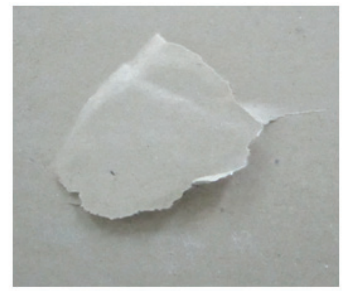

(d)

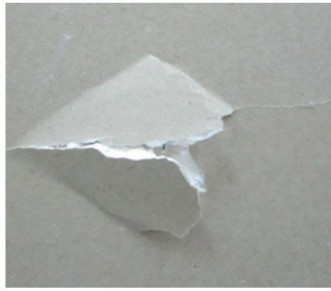

(f)

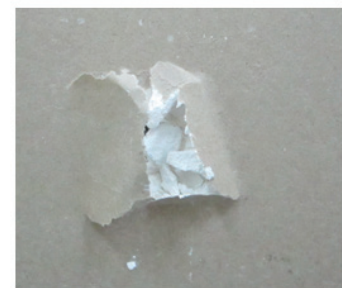

Figure 7 Front and back damaged zones of Gypsum board+wallpaper for (a) $2 \mathrm{~J}$, (b) $4 \mathrm{~J}$, (c) $6 \mathrm{~J}$, (d) $8 \mathrm{~J}$ (e) $10 \mathrm{~J}$, (f) $12 \mathrm{~J}$ impact energy levels
Front view
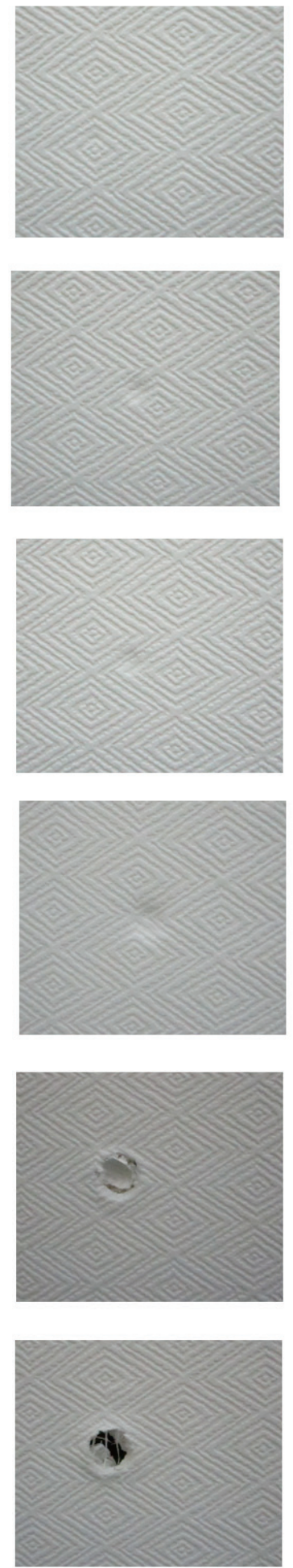

(f)

(d)

(e)

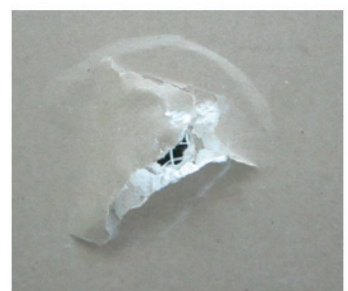

Figure 8 Front and back damaged zones of Gypsum board+mesh+wallpaper for (a) $2 \mathrm{~J}$, (b) $4 \mathrm{~J}$, (c) $6 \mathrm{~J}$, (d) $8 \mathrm{~J}$ (e) $10 \mathrm{~J}$, (f) 12 $\mathrm{J}$ impact energy levels

\section{Conclusions}

In this study, impact resistance of gypsum board subjected to low velocity impact is examined. In the work, low velocity impact tests were carried out on the samples as gypsum boards, gypsum + mesh boards, gypsum+wallpaper boards and gypsum+mesh+wallpaper boards at $2 \mathrm{~J}, 4 \mathrm{~J}, 6 \mathrm{~J}, 8 \mathrm{~J}, 10 \mathrm{~J}, 12 \mathrm{~J}$ impact energies. Impacts are performed by using $24 \mathrm{~mm}$ diameter semi 
spherical tip striker. The results obtained in this study are listed below:

1) For all test samples, while the highest contact force obtained from impact test increases up to the energy level where the striker stuck into the sample, it decreases in the energy levels where puncture occurs.

2) Too much oscillation is observed in force-time and force-displacement curves. Having too much of oscillation is an indicator of increased damages in the samples.

3) Rebound in gypsum plate samples at 2 and $4 \mathrm{~J}$ impact energies, stabbing at $6 \mathrm{~J}$ energy and puncture at $8 \mathrm{~J}$ energy occurred. Rebound in gypsum + mesh samples at 2, 4 and $6 \mathrm{~J}$ impact energies, stab at 8 and $10 \mathrm{~J}$ impact energies and puncture at $12 \mathrm{~J}$ impact energies occurred. Rebound in gypsum+wallpaper samples at 2, 4 and $6 \mathrm{~J}$ impact energies, stab at 8 and $10 \mathrm{~J}$ impact energies and puncture at $12 \mathrm{~J}$ impact energies occurred. Rebound in gypsum+mesh+wallpaper samples at 2, 4, 6 and $8 \mathrm{~J}$ impact energies, stab at $10 \mathrm{~J}$ impact energies and puncture at $12 \mathrm{~J}$ impact energies occurred.

4) In the energy profile diagram obtained as a result of low velocity impact test of composite gypsum plate samples, adding a reinforcement material into the gypsum plate sample is seen to increase the puncture limit. Accordingly, $75 \mathrm{gr} / \mathrm{m}^{2}$ mesh reinforcement increases the puncture limit $58 \%$, wallpaper reinforcement increases it $59 \%$ and mesh+wallpaper reinforcement is observed to increase puncture limit $62 \%$.

5) When the images obtained from low velocity impact damage analysis, damages occurring at the back side are seen to be bigger than the ones occurring in the front side. While the biggest damage in the front side is formed in a way of a puncture with a bigger diameter than the striker's diameters as a result of the striker's stab, cracking type damages occurred at the back side.

\section{Acknowledgments}

This study was carried out as a Master thesis by Müfit Metinöz in the Graduate School of Natural and Applied Science at the University of Selcuk, Konya, Turkey. This work was also supported by Selcuk University Scientific Research Projects for Grant Numbers 12201088.

\section{References}

[1] Chandrasekaran, S.; Nunziante, L.; Serino, G.; Carannante, F. Axial Force-Bending Moment Limit Domain and Flow Rule for Reinforced Concrete Elements Using Euro Code. // International Journal of Damage Mechanics. 19, (2010) pp. 523-558. https://doi.org/10.1177/1056789508101200

[2] Sageresan, N.; Drathi, R.; Anjali, P. S. Numerical Analysis of Concrete Fracture. // International Journal of Damage Mechanics. 19, (2010) pp. 559-573. https://doi.org/10.1177/1056789509102121

[3] Kumar, S.; Barai, S. V. Size-Effect Prediction from the Double-K Fracture Model for Notched Concrete Beam. // International Journal of Damage Mechanics. 19, (2010) pp. 473-497. https://doi.org/10.1177/1056789508101187
[4] Voyiadjis, G. Z.; Taqieddin, Z. N.; Pattan, P. I. Theoretical Formulation of a Coupled Elastic-Plastic Anisotropic Damage Model for Concrete using the Strain Energy Equivalence Concept. // International Journal of Damage Mechanics. 18, (2009), pp. 603-638. https://doi.org/10.1177/1056789508092399

[5] Wu, Y. F.; Dare, M. P. Axial and Shear Behavior of Glass Fiber Reinforced Gypsum Wall Panels: Tests. // Journal of Composites for Construction. 8, (2004), pp. 569-578. https://doi.org/10.1061/(ASCE)1090-0268(2004)8:6(569)

[6] Wu, Y. F. The Effect of Longitudinal Reinforcement on the Cyclic Shear Behavior of Glass Fiber Reinforced Gypsum Wall Panels: Tests. // Engineering Structures. 26, (2004) pp. 1633-1646. https://doi.org/10.1016/j.engstruct.2004.06.009

[7] Hernandez-Olivares, F.; Bollati, M. R.; del Rio, M.; PargaLanda, B. Development of Cork-Gypsum Composites for Building Applications. // Construction and Building Materials. 13, (1999), pp. 179-186. https://doi.org/10.1016/S0950-0618(99)00021-5

[8] Eve, S.; Gomina, M.; Gmouh, A.; Samdi, A.; Moussa, R.; Orange, G. Microstructural and Mechanical Behavior of Polyamide Fiber-Reinforced Plaster Composites. // Journal of the European Ceramic Society. 22, (2002), pp. 22692275. https://doi.org/10.1016/S0955-2219(02)00014-6

[9] Jamshid, A. M.; Ali, S.; Ali, N. Strength Assessment and Bonding Study of Aluminum Short Fiber-Reinforced Gypsum Composites. // International Journal of Damage Mechanics. 21, (2012), pp. 129-149. https://doi.org/10.1177/1056789510397075

[10] Mehaffey, J. R.; Cuerrier, P.; Carisse, G. A Model for Predicting Heat Transfer through Gypsum-Board/WoodStud Walls Exposed to Fire. // Fire and Materials. 18, 5(1994), pp. 297-305. https://doi.org/10.1002/fam.810180505

[11] Sultan, M. A. A Model for Predicting Heat Transfer Through Noninsulated Unloaded Steel-Stud Gypsum Board Wall Assemblies Exposed to Fire. // Fire Technology. 32, 3(1996), pp. 239-259. https://doi.org/10.1007/BF01040217

[12] Thomas, G. Thermal Properties of Gypsum Plasterboard at High Temperatures. // Fire and Materials. 26, 1(2002), pp. 37-45. https://doi.org/10.1002/fam.786

[13] Ghazi, W. K.; Hugi, E. Four Types of Gypsum Plaster Boards and their Thermophysical Properties under Fire Condition. // Journal of Fire Sciences. 27, (2009), pp. 2742. https://doi.org/10.1177/0734904108094514

[14] Buzzini, D.; Dazio, A.; Trüb, M. Quasi-Static Cyclic Tests on Three HybridFibre Concrete Structural Walls. // IBK Report Nr. 297. / Institute of Structural Engineering. / Swiss Federal Institute of Technology Zurich. / Zurich / Switzerland, 2006

[15] Chen, Y.; May, I. M. Reinforced Concrete Members under Drop-Weight Impacts. // Proceedings of Institution of Civil Engineers. / Structure and Buildings. 162, (2009), pp. 4556. https://doi.org/10.1680/stbu.2009.162.1.45

[16] Hummeltenberg, A.; Beckmann, B.; Weber, T.; Curbach, M. Investigation of Concrete Slabs under Impact Load. // Applied Mechanics and Materials. 82, (2011), pp. 398-403. https://doi.org/10.4028/www.scientific.net/AMM.82.398

[17] Kishi, N.; Kurihashi, Y.; Ghadimi Khasraghy, S.; Mikami, H. Numerical Simulation of Impact Response Behavior of Rectangular Reinforced Concrete Slabs under FallingWeight Impact Loading. // Applied Mechanics and Materials. 82, (2011), pp. 266-271. https://doi.org/10.4028/www.scientific.net/AMM.82.266

[18] Mougin, J. P.; Perrotin, P.; Mommessin, M.; Tonnelo, J.; Agbossou, A. Rock Fall Impact on Reinforced Concrete Slab: An Experimental Approach. // International Journal of Impact Engineering. //31, (2005), pp. 169-183 https://doi.org/10.1016/j.jijmpeng.2003.11.005

[19] Schellenberg, K. On the Design of Rockfall Protection Galleries. // Institute of Structural Engineering. / Swiss 
Federal Institute of Technology Zurich. / Zurich / Switzerland, 2009

[20] Zineddin, M.; Krauthammer, T. Dynamic Response and Behaviour of Reinforced Concrete Slabs under Impact Loading. // International Journal of Impact Engineering. 34, (2007), pp. 1517-1534.

https://doi.org/10.1016/j.ijimpeng.2006.10.012

[21] Uyaner, M.; Kara, M. Dynamic response of laminated composites subjected to low-velocity impact. // Journal of Composite Materials. 41, 24(2007), pp. 2877-2895. https://doi.org/10.1177/0021998307079971

[22] Liua, D.; Rajub, B. B.; Danga, X. Impact Perforation Resistance of Laminated and Assembled Composite Plates. // International Journal of Impact Engineering. 24, (2000) pp. 733-746. https://doi.org/10.1016/S0734-743X(00)00021-X

\section{Authors' addresses}

Memduh Kara, Assit. Prof. Dr.

Mersin University, Engineering Faculty,

Dept. of Mechanical Eng.

Ciftlikköy Campus, 33343 Yenisehir/Mersin, Turkey

memduhkara@mersin.edu.tr

Müfit Metinöz, Postgraduate

Selçuk University, Graduate School of Natural and Applied

Science at the University of Selcuk,

42075 Konya, Turkey

mufit.10@hotmail.com

Mesut Uyaner, Prof. Dr.

Selçuk University, Engineering Faculty,

Dept. of Metall. and Material Eng.

42130 Konya, Turkey

muyaner@selcuk.edu.tr 